1 EFFECTIVENESS OF INCENTIVES ON ELECTRIC VEHICLE ADOPTION IN

2 NORWAY

3

4 Avi Chaim Mersky

5 Ph.D. student

6 Department of Civil and Environmental Engineering

7 Carnegie Mellon University

8 Pittsburgh, PA, 15213

9 Email: amersky@andrew.cmu.edu

11 Frances Sprei

12 Assistant Professor,

13 Division of Physical Resource Theory

14 Chalmers University of Technology

15 SE-412 96 Gothenburg, Sweden

16 Email: fsprei@chalmers.se

\title{
Constantine Samaras
}

Assistant Professor

Department of Civil and Environmental Engineering

Carnegie Mellon University

Pittsburgh, PA, 15213

Email: csamaras@cmu.edu

\section{Zhen (Sean) Qian, corresponding author}

Assistant Professor

Department of Civil and Environmental Engineering and Heinz College

Carnegie Mellon University

Pittsburgh, PA, 15217

30 Email: seanqian@cmu.edu

31

32

33

34 


\section{ABSTRACT}

2 Battery Electric vehicles (BEVs) shift pollution off the road and to potentially less damaging and 3 more varied sources than petroleum. Depending on the source of electricity, a transition to 4 electrified personal transportation can dramatically reduce greenhouse gas emissions and air 5 pollutants. However current EVs tend to be more expensive and have shorter range, which can 6 hinder public adoption. Government incentives can be used to alleviate these factors and

7 encourage adoption. Norway has a long history incentivizing BEV adoption including measures

8 such as exemption from roadway tolls, access to charging infrastructure, point of sale tax

9 incentives, and usage of public bus use limited lanes. This paper analyzed the sales of electric

10 vehicles on a regional and municipal basis in Norway and then cross analyzed these with the 11 corresponding local demographic data and incentive measures to attempt to ascertain which 12 factors lead to higher BEV adoption. It was concluded that access to BEV charging 13 infrastructure, being adjacent to major cities, and regional incomes had the greatest predictive 14 power for the growth of BEV sales. It was also concluded that short-range vehicles showed 15 somewhat more income and unemployment sensitivity than long-range vehicles. Toll exemptions 16 and the right to use bus designated lanes do not seem to have statistically significant predictive 17 power for BEV sales in our linear municipal-level models, but this could be due to neighboring 18 major cities containing those incentive features.

19 Keywords: Electric Vehicle, BEV, Norway, Incentive, Policy 


\section{INTRODUCTION}

Electric vehicles (EVs), specifically Battery EVs (BEVs), which do not require petroleum fuel, can provide many benefits over internal combustion engine-based vehicles. They produce no onroad greenhouse gas (GHG) emissions or criteria air pollutants and the upstream pollution they do produce can be considerably less severe, depending on the electricity source used for battery charging and the energy intensity of manufacturing (Holdway et al., 2010; Michalek et al., 2011; Samaras and Meisterling, 2008). In addition, since electricity can be produced from a variety of conventional and renewable technologies, BEVs allow for diversification of transportation energy sources. BEVs however, have limitations compared to their internal combustion competitors. They are currently more expensive, have more limited ranges, longer refueling times and fewer public infrastructure refueling opportunities than petroleum-fueled vehicles (“Alternative Fueling Station Counts by State," 2014; Traut et al., 2013). Additionally charging technology is significantly slower than refueling with liquid hydrocarbons. As with other technologies that provide environmental benefits, governments have used various policy mechanisms to encourage BEV adoption (Michalek et al., 2012; Skerlos and Winebrake, 2010). Using an analysis of Norway's experience in encouraging BEVs, this paper makes a contribution to the literature by examining the sales of electric vehicles in Norway on a regional and municipal basis and cross analyzing those with corresponding local demographic data and incentive measures to examine which factors lead to higher BEV adoption at a local level. The maturity of the Norwegian BEV market enables this study to inform BEV policy more broadly, as other countries prepare their own incentives and support regimes for BEVs.

Norway has a long history of research and government incentives for battery powered electric vehicles (BEVs, EV used equivalently). Its EV market has been described as going through "five distinct phases" (Erik Figenbaum and Marika Kolbenstvedt, 2013). The concept development phase took place from 1970-1990; consisting of the government funding private companies, to produce Norway's first modern EV prototypes. This was followed by the first test phase, from 1990-1999, in which the first government incentives were offered, to encourage commercialization. These included vehicle-related tax exemptions, toll exemptions and free parking in spaces owned by certain municipalities. This phase ended with the bankruptcy of Think Motors and Kewet, the two providers of EVs in the market. Next was the third phase, from 1999-2009, characterized by sporadic EV supply. Ford bought Think and introduced a new model to market, but then divested and Think went through several owners and bankruptcies. During this phase small imports of French EVs compensated for the stoppage of local production and the government allowed EVs free usage of bus only lanes and discounts on car ferries. 20092013 was characterized as the market introduction phase. In this period two new local companies, a reestablished Think and Pure mobility, entered the EV market and were joined by major manufactures such as Mitsubishi, Peugeot and Nissan. Price competition made EVs more affordable, but also led to the re-bankruptcy of the Norwegian EV manufacturers. In addition, the Norwegian government started building public charging stations in 2009 (with fast charging stations being built in early 2011) and Plug-in Hybrid Electric Vehicles (PHEVs) also entered the market, with reduced incentives. The current phase of the Norwegian EV market, starting in 2013, is characterized by a more rapid market expansion. EVs sales passed 10,000 units, and municipalities increased the EV share of their fleets (Erik Figenbaum and Marika Kolbenstvedt, 2013). 
1 Concurrent with the incentives offered in these phases has been a large growth in EV sales, with 2 the EV share of new car sales growing to 5\% by September 2012 (Håvard Vaggen Malvik et al., 3 2013). Absolute sales in Norway have reached numbers comparable to much larger countries 4 such as France and Germany, thus making Norway an outstanding example of EV sales success 5 (Håvard Vaggen Malvik et al., 2013). Figure 1 shows the growth of EV sales from 2000 to 2013. 6 As can be seen, sales have increased rapidly since the latter half of 2010, when the government 7 started its EV charging program. Therefore the period of 2011-2013 was chosen as this paper's 8 study period, to reflect all incentives being available to Norway consumers.

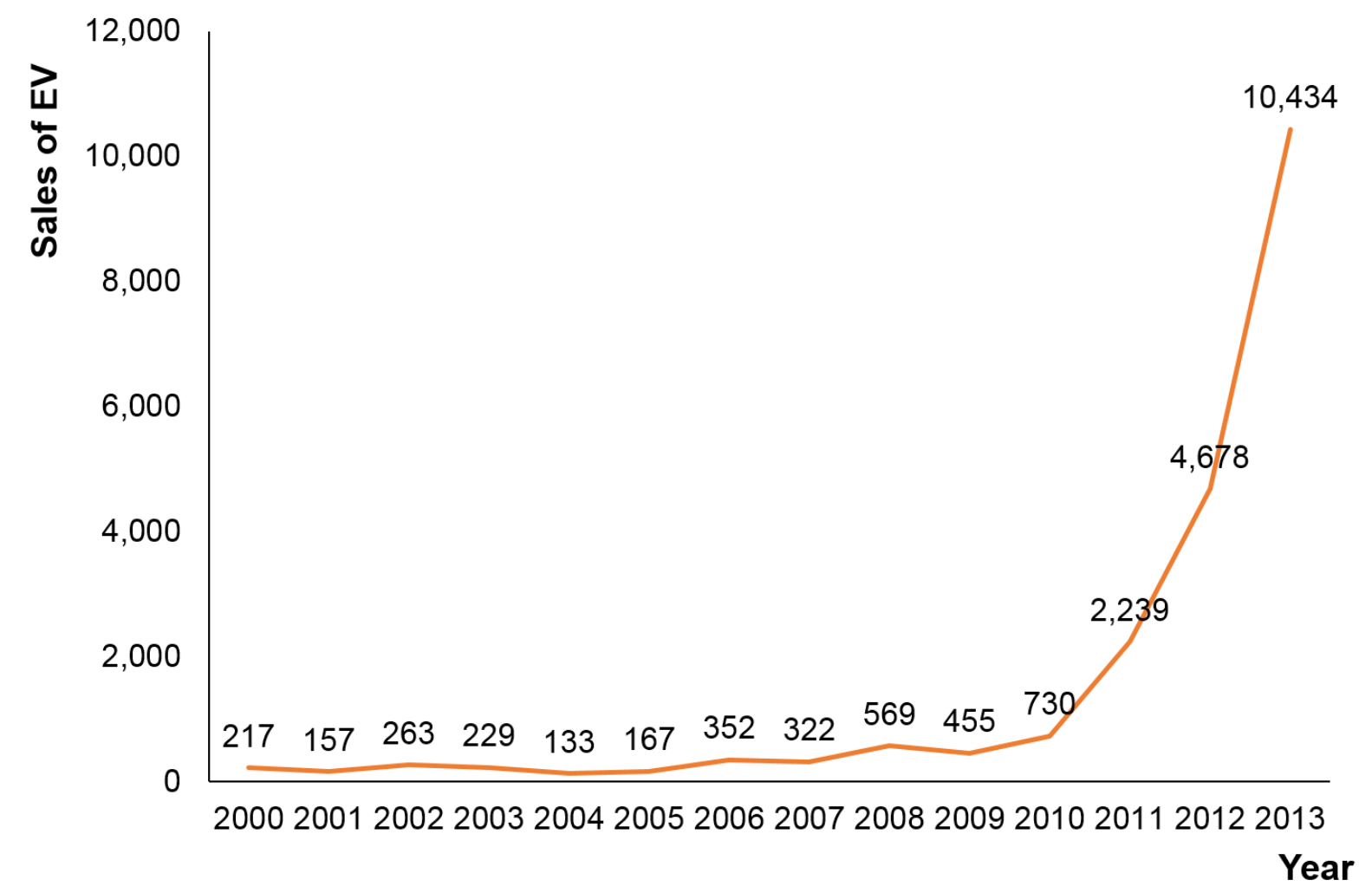

Figure 1 EV sales 2000-2013

Table 1 summarizes the incentives described above and their dates of introduction. In total the incentives can be summed up to be somewhere in between 12000 to 20000 Euro depending on how they are calculated (Sprei and Bauner, 2011; Mock and Yang, 2014) ${ }^{1}$. These can be compared to the US, where the federal and some state governments offer a tax credit to buyers and several states offer free access to High Occupancy Vehicle lanes ("Electric Vehicle Incentives around the world," 2014). In addition, some cities and municipalities offer other benefits, including reduced electric rates and parking benefits ("Electric Vehicle Incentives around the world," 2014). Other EU countries also have EV incentives. For example, the UK, France and Sweden offer purchase incentives, however none of these amount to the same reduction of costs as the tax exemptions in Norway. The only other country with similar high incentives is Denmark. For PHEVs, the Netherlands also has a high level of incentives. While

\footnotetext{
${ }^{1}$ For example the exclusion of registration tax will depend on which vehicle is used as a comparison and the exemption from VAT will of course depend on the purchase price of the vehicle.
} 
many other countries offer benefits similar to Norway on a combined national-regional basis, Norway is unique in that it has a nationally uniform policy that includes every major incentive category: parking access, infrastructure usage pricing benefits, point of sale pricing benefits, infrastructure access benefits, and charging access benefits. The only benefit category not covered nationally in Norway that is covered elsewhere, is fuel pricing benefits. This is a benefit only offered regionally, in the form of reduced EV electricity rates, in some of the other named countries. Norway also has the longest continuous support for EVs, which has allowed the market time to mature and increased visibility of EVs an important factor in the diffusion of a new technology (Eppstein et al 2011).

Table 1 Norwegian EV Policy Time Period of Introduction

\begin{tabular}{|l|l|}
\hline EV Policy Incentive & $\begin{array}{l}\text { Time Period of } \\
\text { Introduction }\end{array}$ \\
\hline Exemption from Registration Tax (Figenbaum and Kolbenstvedt, 2013) & $1990 \mathrm{~s}$ \\
\hline Free public Parking (Erik Figenbaum and Marika Kolbenstvedt, 2013) & $1990 \mathrm{~s}$ \\
\hline $\begin{array}{l}\text { Toll Exemptions (Erik Figenbaum and Marika Kolbenstvedt, 2013) } \\
\text { Kolbenstvedt, 2013) }\end{array}$ & $1990 \mathrm{~s}$ \\
\hline $\begin{array}{l}\text { Bus Lane Access (Erik Figenbaum and Marika Kolbenstvedt, 2013) } \\
\text { Reduced Ferry Rates (Håvard Vaggen Malvik et al., 2013) }\end{array}$ & $\begin{array}{l}2003 \text { (Oslo) and 2005 } \\
\text { (Nationwide) }\end{array}$ \\
\hline $\begin{array}{l}\text { Public EV Charging Station Construction (Erik Figenbaum and Marika } \\
\text { Kolbenstvedt, 2013) }\end{array}$ & 2009 \\
\hline
\end{tabular}

12 Most empirical studies that estimate sales of vehicles and the role of incentives are based on 13 hybrid electric vehicles or PHEVs. Beresteanu \& Li (Berensteanu, A. and Li, S, 2011) develop a 14 market equilibrium model with both demand and supply side based on hybrid sales statistics 15 from multiple municipalities. They conclude that about $25 \%$ of hybrid sales result from 16 incentives. Chandra et al (Chandra, A. et al., 2010) perform regression analysis on sale shares of 17 hybrids in Canada and find that tax rebates generate about $25 \%$ of the hybrid sales. De Haan et al 18 (De Haan, P. et al., 2007) instead rely on surveys of consumers who recently purchased a Toyota 19 Prius and as control other equivalent non- hybrid Toyota models. Their main purpose is to assess 20 if there is a rebound effect of purchasing a hybrid but they also conclude that tax rebates increase sales of hybrids. Jenn et al. (Jenn et al., 2013) found that U.S. sales of hybrid vehicles increased by $0.0046 \%$ per dollar of incentive, but only when the incentive provided was greater than $\$ 1000$

23 (Jenn et al., 2013). 
Gallagher and Muehlegger investigated the effect of state incentives on hybrid vehicle sales in the United States (Gallagher and Muehlegger, 2011). They focused on tax benefits, single driver use of carpool lanes and gas prices. They concluded that state tax benefits had a significant effect on increasing hybrid vehicle sales. In addition they found a modest increase in sales correlated with rising gasoline prices and little to no significant correlation of sales with access to carpool lanes. Diamond (Diamond, 2009) similarly looked into US state level incentives on hybrid vehicle adoption, focusing on the growth of market share. Diamond concluded that rising gas prices were a much more significant incentive to increase hybrid market share than direct vehicle price tax incentives and that while tax incentives do have an effect, they are too costly to be viable. In addition, he concluded that commuter lane allowances were significant, but observed that much of that conclusion is based on one state, Virginia, which is consistent with Gallagher and Muehlegger's conclusions (Gallagher and Muehlegger, 2011).

Since total EV sales are still a small percentage of overall vehicle sales, previous studies have primarily relied on stated preferences (Axsen, J. et al., 2009; Bolduc et al., 2008; Brownstone et al., 2000) or a model of the vehicle market demand (Eppstein et al., 2011; Mau et al., 2008; Mueller and de Haan, 2009). One recent stated preference study was conducted by Axsen and Kurani in San Diego (Axsen and Kurani, 2013). They compared stated preference for Hybrids, PHEVs and BEVs and found that a majority of respondents showed preference for PHEV, with the main reasons being the high costs and limited range and refueling opportunities of BEV while still wanting to support the environment and nation, by reducing gasoline consumption (Axsen and Kurani, 2013). Based on the National Research Council study, Transitions to Alternative Vehicles and Fuels (National Research Council, 2013), Greene, Par and Liu, develop scenarios predicting the growth of EV vehicles, and find a great deal of uncertainty around the areas of both technological change, and government policy, suggesting the importance of actions affecting those areas (Greene et al., 2014).

There are a few international comparisons that try to assess the role of incentives in the sales of EVs. Sprei and Bauner (Sprei and Bauner, 2011) looked at the role of consumer incentives in 14 countries during the years 2009 to 2011 . They found that incentives have a statistically significant effect but that effect is small and thus very high incentives are needed to significantly increase sales. Mock and Yang (Peter Mock and Zifei Yang, 2014) compared fiscal incentives for BEVs and PHEVs in different countries. They concluded that fiscal incentives matter but that a direct relationship between incentives and EV sales is unclear, noting that the UK has seen a limited market growth despite financial incentives in place. The IEA summarized sales and market conditions for EVs at a global level (Global EV Outlook, 2013). Sierzchula et al (Sierzchula et al., 2014) performed regression analysis on sales of EVs in 30 different countries and found financial incentives, charging stations and the presence of a local EV manufacturer as the most important factors contributing to sales. They found charging infrastructure availability to be the best predictor. Sánchez-Braza et al (Sánchez-Braza et al., 2014), rather than specifically looking at sales of EVs, compared municipalities in Spain and their choice of introducing EVincentives and found that the size as well as distribution of population and environmental commitment were important factors. 
EV incentives have advanced EV sales in Norway, which is reported in the literature. Malvik, Hannisdahl and Wensaas (Håvard Vaggen Malvik et al., 2013) investigated electric vehicle incentives and adoption across several European Union states, as well as their main focus state of Norway. They noted Norway's high EV sales per capita and tried to ascertain their causes. The report's methodology relied on noting which incentives in Norway were greater than, or exclusive from, the other studied countries, as well as a local analysis. The local analysis tended to focus on timings of EV sales spikes and the introduction of localized incentives. They concluded that, while the combination of incentives was important, import and sales/VAT tax exemptions were likely the greatest factors. Figenbaum and Kolbenstvedt (Erik Figenbaum and Marika Kolbenstvedt, 2013) present a comprehensive report on the development of EVs sales in Norway providing both a historical perspective as well as looking at incentives, policies and charging infrastructure. Bjerkan et al (Bjerkan et al., 2016) used surveys to look at stated importance of different incentives and found pricing, toll and bus lane access to be the most important.

This paper makes a contribution to the literature by analyzing individual EV sales in Norway and providing a more detailed assessment of the role of local incentives, as well as the distinction between private and business consumers within a country with a more mature EV market.

The remainder of this paper is organized as follows: Section 2 discusses the sources and content of the data used in the paper, Section 3 describes the methodology used, Section 4 reports the results, Section 5 discusses the results and draws conclusions and Section 6 summarizes the paper and notes its limitations and potential future work.

\section{DATA}

The Norwegian government has made detailed BEV sales data available for this study, making a refined analysis from either the macro or single vehicle sale level possible. These data are described below.

\subsection{Municipalities and Regions in Norway}

Norway is divided into 430 municipalities. For official government statistical data, including the sales data used for this analysis, this is the lowest level of locality precision given. These municipalities are grouped into 20 different Counties, hereafter referred to as regions. Oslo is the sole municipality to constitute its own region, in entirety. Some municipalities have gone through consolidation and mergers. Between 2011 and 2013 two municipalities were merged out; Mosvik was incorporated into Inderoy and Bjarkoy was incorporated into Harstad ("Population," 2014). For the purposes of this study municipalities and their sales and demographic data reflect the municipal borders at the end of 2013. Data from the previous years were merged together, from the constituent municipalities, into the borders of the more recent one.

We found that 163 municipalities do not have EV sales from 2000 to 2013. This is because the division into municipalities and counties is an administrative division, thus a large share of these municipalities are not cities in the traditional meaning but rather rural areas, many with a very 
low number of inhabitants and thus no EV sales. In addition, many municipalities (especially those rural ones) do not have EV dealerships. For data consistency, the municipalities with no sales of EVs have been excluded from the analysis.

\subsection{Incentive Data}

The Norwegian government has provided several incentives for the private adoption of electric vehicles. These include free parking, access to public bus lanes, road toll waivers, a free network of EV charging stations and tax benefits (Erik Figenbaum and Marika Kolbenstvedt, 2013)(Håvard Vaggen Malvik et al., 2013). Free parking and tax benefits were excluded from this analysis. Parking benefits were excluded as data at the municipal level were not available. Tax benefits, both point of sale and whole life, were excluded as they were constant across Norway. The incentives studied here have been considered in previous studies, such as both Malvik and Figenbaum's earlier research on EV developments in Norway (Erik Figenbaum and Marika Kolbenstvedt, 2013; Håvard Vaggen Malvik et al., 2013) and Gallagher and Diamond's investigations into EV sales among the States in USA (Diamond, 2009; Gallagher and Muehlegger, 2011). The newer comprehensive Norwegian data should help to further the understanding of these incentives' effects.

Access to public bus lanes and road tolls were modeled as true/false binaries, measuring if they were present in the municipality. A municipality or region containing at least one restricted access bus lane and no toll roads would have values of 1 and 0 for the bus lane and toll road variables, respectively. Information about tolls was obtained from AutoPass the official website about road tolls in Norway ("Find a toll station," 2013). Data on bus lanes were collected from individual websites of the major cities in Norway. Vehicle charging points were taken as the absolute number of electric vehicle charging points open to the public, both privately owned and for fee and public and free, in the municipality in as reported in the charge point database of NOBIL. 2012 (http://www.elbil.no/nobil/index.php/english) was selected as the midpoint among the years studied, as this study looks only at location sensitivities, omitting time sensitivities.

Each of the previously listed measures was observed to be significantly correlated with high municipal populations. To model their effects on commuters, who may be traveling from nearby, less populated regions, another binary measure, testing if a city of population 150,000 or greater was adjacent, was used. Additionally this measure was set to true for cities that fulfilled this condition themselves. Table 2 shows the cities fulfilling the population requirement, their region, and the neighboring municipalities, by the distance definition given above.

\section{Table 2 Major Cities and Neighbors by Region}

\begin{tabular}{|c|c|c|c|}
\hline Major city & Region & Neighboring region & Neighboring municipalities \\
\hline \multirow{3}{*}{ Oslo } & \multirow{3}{*}{ Oslo } & Akershus & Bærum \\
\cline { 3 - 3 } & & & Asker \\
\cline { 3 - 4 } & & & Nesodden \\
\hline
\end{tabular}




\begin{tabular}{|c|c|c|c|}
\hline & & & Oppegård \\
\hline & & & Ski \\
\hline & & & Enebakk \\
\hline & & & Lørenskog \\
\hline & & & Skedsmo \\
\hline & & & Nittedal \\
\hline & & \multirow{2}{*}{ Oppland } & Jevnaker \\
\hline & & & Lunner \\
\hline & & \multirow{5}{*}{ Buskerud } & Ringerike \\
\hline & & & Hole \\
\hline & & & Lier \\
\hline & & & Røyke \\
\hline & & & Hurum \\
\hline \multirow{6}{*}{ Bergen } & \multirow{6}{*}{ Hordaland } & \multirow{6}{*}{ Hordaland } & Arna \\
\hline & & & Haus \\
\hline & & & Åsane \\
\hline & & & Askøy \\
\hline & & & Laksevåg \\
\hline & & & Birkeland \\
\hline & & & Malvik \\
\hline Trondheim & Sør-Trøndelag & Sør-Trøndelag & Kæbu \\
\hline & & & Melhus \\
\hline & & & Randaberg \\
\hline Stavanger & Rogaland & Rogaland & Sola \\
\hline & & & Sandnes \\
\hline
\end{tabular}




\subsection{Sales Data}

Sales data were obtained from Norwegian Road ("Opplysningsrådet for Veitrafikken," n.d.), an organization of parties involved in road transport in Norway. Early data were supplied by Green Car, a project funded by a Norwegian organization aimed at diminishing the $\mathrm{CO}_{2}$ emissions from the Norwegian transportation sector (“Grønn Bil," 2014).

These data include every electric vehicle sale in Norway, as well as the municipality of the sale, the manufacturer and model of the vehicle and the gender of the buyer, or if the buyer was a corporation. The data range from 2000 to 2013. This is the first such examination of this complete dataset.

\section{$12 \quad 2.4$ Demographic Data}

13 Demographic data, the municipalities' median household income, after taxes, in NOK, and 14 unemployment rate, were obtained from Statistics Norway ("Registered unemployed," 2014) ("Households' income, geographic distribution," 2014). The unemployment rate came from 2012 data, while the income came from 2011. The average vehicle kilometers traveled, by personal vehicles, was obtained from Statistics Norway ("Vehicle Kilometers Travelled," 2014), for the 2012. Median household income, after taxes, was chosen to reflect the spending power of the decision making unit, which this paper considers better represented by the household than individual. This is because it is not uncommon for earners to purchase vehicles for non-earners in the household. Data were left in the local currency to avoid any distortion from currency fluctuations. The unemployment rate used was the registered unemployment rate. This was chosen over other employment measures because it is the most general employment measurement provided by Statistics Norway on a municipal level. All information was collected at the municipal level. Population in 2012 for each of the municipalities was also collected, from Statistics Norway("Population," 2014), but not directly used as an independent variable in the model. Table 3 summarizes the characteristics of the collected data for all Municipalities used.

\section{Table 3: Data Characteristics of the 265 Municipalities Used}

\begin{tabular}{|l|l|l|l|l|}
\hline Data & Mean & Standard Deviation & Min & Max \\
\hline $\begin{array}{l}\text { Municipal } \\
\text { Population (people) }\end{array}$ & 17,000 & 42,000 & 210 & 580,000 \\
\hline $\begin{array}{l}\text { Municipal Income } \\
\text { (kroner) }\end{array}$ & 450,000 & 45,000 & 370,000 & 580,000 \\
\hline $\begin{array}{l}\text { Municipal Average } \\
\text { Vehicle Kilometers }\end{array}$ & 13,000 & 1,000 & 9,400 & 16,000 \\
\hline
\end{tabular}




\begin{tabular}{|l|l|l|l|l|}
\hline Traveled & & & & \\
\hline $\begin{array}{l}\text { Charging Points in } \\
2012\end{array}$ & 22 & 140 & 0 & 2,000 \\
\hline $\begin{array}{l}\text { Total EV sales } \\
(2011-13) \text { (vehicles) }\end{array}$ & 67 & 200 & 0 & 1800 \\
\hline $\begin{array}{l}\text { Male EV sales } \\
\text { (2011-13) (vehicles) }\end{array}$ & 31 & 83 & 0 & 810 \\
\hline $\begin{array}{l}\text { Female EV sales } \\
\text { (2011-13) (vehicles) }\end{array}$ & 18 & 63 & 0 & 680 \\
\hline $\begin{array}{l}\text { Corporate EV sales } \\
\text { (2011-13) (vehicles) }\end{array}$ & 18 & 70 & 0 & 680 \\
\hline
\end{tabular}

3. METHODS

\subsection{Sale and vehicle classification and division}

This study investigated only freeway legal passenger battery operated electric vehicles. Plug in hybrids were not included as their major introduction to the market started in late 2012, during the period of study. Additionally, PHEV sales are still quite small and they are given a different set of incentives than those studied here. Golf carts, trucks and motorcycles were excluded to focus on the passenger vehicles that have the most mileage. The vehicles investigated were further separated into two groups, short-range vehicles and long-range vehicles. Short-range vehicles are those with a range of $100 \mathrm{~km}$ or less, while long-range exceed $100 \mathrm{~km}$. The $100 \mathrm{~km}$ threshold was used as both a price proxy and as a commuter-only and long-range division. As the average commute in Norway is 32 minutes ("Working time in the European Union: Norway," 2009) with freeway speed limits being $80 \mathrm{~km} / \mathrm{h}$ the average daily commute is approximately 85 $\mathrm{km}$. This makes a $100 \mathrm{~km}$ range sufficient for most commutes, but not for a longer vacation trip. Price itself was not used as a factor. Cars in each group were assumed identical; a separate paper will investigate the differences between EV models, within the groups, and sales.

17 The groupings of the vehicles are as follows. As the dataset used here was only EVs, only the vehicle make and year are listed. Only Volkswagen had more than one EV model per year. Short-range vehicles included Buddy Electric, Piaggio, Renault, Citroen and Volkswagen Citystromers. Long-range vehicles included Toyota, Chevy, Fiat, Ford, Mia, Mitsubishi, Nissan, Peugeot, Smart, Think, Tesla, Volkswagen up!s, Tazzari, Baoya Variant 1A, BMW i3 and Mercedes-Benz SLS. This list is only for the years 2011 through 2013 (“Grønn Bil,” 2014); EV manufacturers listed for only long range vehicles did sell short range vehicles in earlier years.

\section{$24 \quad 3.2$ Regional Aggregation}


All regional level sales and demographic data, with the exception of the unemployment rate, vehicle kilometers traveled and median household income, were summed directly from the municipalities with EV sales into their regional units. Only municipalities with non-zero EV sales were considered and the other municipalities in the regions were omitted. The other measures were taken as the average, weighted by municipal population.

$$
\text { Regional value }=\frac{\sum \text { Municipal value } * \text { Municipal Population }}{\sum \text { MunicipalPopulations }}
$$

The binary measures, showing the presence of tolls, bus lanes and major cities were kept as binary measures in the region. The binary measures in the region are taken as positive when at least one municipality in this region has toll, bus lanes or major cities present. Initial analyses were run with both pure binary and various scaled measures, for aggregations of the binary variables. These however, never offered significant improvements and were often worse and therefore dropped from the investigation.

\subsection{Regression Methods}

Sales for each municipality, region and vehicle category were divided by the area's population to find EV sales per capita. This was used as the dependent variable for all linear regressions. Sales per capita was chosen, as the dependent measure, over absolute sales, in order to estimate the independent variables' effect on the likelihood of one potential purchaser choosing to buy an EV. Using absolute sales would have hidden that with the effect of population. In addition, sales to people and sales to corporations were separated as their own groups, in order to test how the incentives worked differently on the two different buyers. The independent variables in the linear regressions were:

- The area's unemployment rate

- Median hou sehold income

- Average vehicle kilometers traveled

- Number of EV charging stations

- The presence of tolls (as a binary)

- The presence of bus lanes (as a binary)

- If the area bordered a major city, as defined previously in Data, Demographic Data (as a Binary)

These variables were used in standard linear regression form, that is,

$$
\text { EV Sales Per Capita }=\text { Constant }+X_{1} \text { Unemplyment }+\cdots X_{7} \text { MajorCity }
$$

Gasoline prices were not included since, over the year the variation among municipalities in Norway is low. One of the main reasons is that a large share of the price is determined both by taxes, roughly $60 \%$, and by oil market prices, at least $30 \%$ (see e.g. www.statoil.no). 
1 The independent variables are selected using a stepwise, forward selection procedure optimizing for Akaike information criterion (AIC). In addition the R-squared values for a linear regression

3 model of sales per capita versus each of the independent variables were calculated and recorded, 4 along with the direction of the correlation. The process was used first to find a standard linear model. Next, to see if the linear model was appropriate, common log regression analyses were also run, with the log of per capita sales and income being used instead of their absolutes. Log for sales per capita and for income is sometimes recommended in the econometric literature when the data are not normally distributed (Peter Kennedy, 2008). However, log transformation may not be appropriate for this paper since this study adopted median income, for each municipality, instead of categorical income levels. This study ran both the regular model and logtransformed model, to select the one with more statistical significance.

\section{4. RESULTS}

\section{$13 \quad 4.1$ Regressions}

14 Tables 4 and 5 present results of the final linear regression models that were produced. An "-" is used for variables that were not included in the final model. Scientific notation was used for the independent variable coefficients to allow for proper precision, while reflecting the difference in scales of the variables. The log-linear results appear less reliable than the linear ones, generally having low R-squared values, not being better than a constant in others and occasionally switching correlation directions. For these reasons the linear results were taken as the superior and final results for deriving conclusions. Figures 2-5 show actual and predicted EV sales per

21 capita.

Table 4 Linear Municipal Regression Results

\begin{tabular}{|c|c|c|c|c|}
\hline $\begin{array}{l}\text { coefficient } \\
\text { (p-value) }\end{array}$ & $\begin{array}{c}\text { Short range, } \\
\text { consumers }\end{array}$ & $\begin{array}{c}\text { Long range, } \\
\text { consumers }\end{array}$ & Short range, business & $\begin{array}{c}\text { Long range, } \\
\text { business }\end{array}$ \\
\hline Constant & $\begin{array}{c}0.00 \\
(0.124) \\
\end{array}$ & $\begin{array}{c}-0.01 \\
(0.047)\end{array}$ & $\begin{array}{c}0.00 \\
(0.510) \\
\end{array}$ & $\begin{array}{c}0.00 \\
(0.000)\end{array}$ \\
\hline $\begin{array}{l}\text { Unemployment } \\
\text { rate (2012) }\end{array}$ & $\begin{array}{l}- \\
-\end{array}$ & - & $\begin{array}{c}5.17 \mathrm{E}-06 \\
(0.086)\end{array}$ & - \\
\hline $\begin{array}{l}\text { Income after } \\
\text { taxes, median } \\
\text { (NOK) }\end{array}$ & $\begin{array}{c}1.68 \mathrm{E}-10 \\
(0.043)\end{array}$ & $\begin{array}{c}2.33 E-08 \\
(0.000)\end{array}$ & $\begin{array}{l}- \\
-\end{array}$ & $\begin{array}{l}- \\
-\end{array}$ \\
\hline VKT 2012 & $\begin{array}{l}- \\
-\end{array}$ & $\begin{array}{c}-3.07 \mathrm{E}-07 \\
(0.029)\end{array}$ & $\begin{array}{l}- \\
-\end{array}$ & $\begin{array}{l}- \\
-\end{array}$ \\
\hline 2012 chargers & - & $\begin{array}{l}- \\
-\end{array}$ & $\begin{array}{c}1.57 \mathrm{E}-07 \\
(0.000)\end{array}$ & $\begin{array}{c}1.75 \mathrm{E}-06 \\
(0.035)\end{array}$ \\
\hline Toll yes/no & - & - & $\begin{array}{l}- \\
- \\
\end{array}$ & $\begin{array}{l}- \\
-\end{array}$ \\
\hline $\begin{array}{l}\text { Bus lane } \\
\text { yes/no }\end{array}$ & $\begin{array}{c}2.73 E-05 \\
(0.129)\end{array}$ & - & - & $\begin{array}{c}0.001 \\
(0.027)\end{array}$ \\
\hline $\begin{array}{l}\text { Major City } \\
\text { (yes/no) }\end{array}$ & $\begin{array}{c}2.42 \mathrm{E}-05 \\
(0.127) \\
\end{array}$ & $\begin{array}{c}0.002 \\
(0.001)\end{array}$ & $\begin{array}{c}1.76 \mathrm{E}-05 \\
(0.039)\end{array}$ & $\begin{array}{c}0.001 \\
(0.002)\end{array}$ \\
\hline R-squared & 0.063 & 0.218 & 0.105 & 0.158 \\
\hline
\end{tabular}


Table 5 Linear Regional Regression Results

\begin{tabular}{|c|c|c|c|c|}
\hline $\begin{array}{l}\text { coefficient/ } \\
p \text {-value }\end{array}$ & $\begin{array}{l}\text { Short range, } \\
\text { consumers }\end{array}$ & $\begin{array}{l}\text { Long range, } \\
\text { consumers }\end{array}$ & Short range, business & $\begin{array}{l}\text { Long range, } \\
\text { business }\end{array}$ \\
\hline Constant & $\begin{array}{c}6.47 \mathrm{E}-06 \\
(0.094) \\
\end{array}$ & $\begin{array}{c}0 \\
(0)\end{array}$ & $\begin{array}{l}1.99 \mathrm{E}-4 \\
(0.009)\end{array}$ & $\begin{array}{c}0.00 \\
(0.000)\end{array}$ \\
\hline $\begin{array}{l}\text { Unemployment } \\
\text { rate (2012) }\end{array}$ & - & - & - & - \\
\hline income & - & - & $\begin{array}{c}-4.434 \mathrm{E}-10 \\
(0.011)\end{array}$ & - \\
\hline VKT 2012 & $\begin{array}{l}- \\
-\end{array}$ & $\begin{array}{l}- \\
-\end{array}$ & $\begin{array}{l}- \\
-\end{array}$ & $\begin{array}{l}- \\
-\end{array}$ \\
\hline $\begin{array}{l}\text { Sum Of } 2012 \\
\text { chargers }\end{array}$ & $\begin{array}{l}9.64 \mathrm{E}-08 \\
(0.000)\end{array}$ & $\begin{array}{c}2.09 \mathrm{E}-06 \\
(0.000)\end{array}$ & $\begin{array}{c}1.08 \mathrm{E}-07 \\
(0.000)\end{array}$ & $\begin{array}{c}2.09 \mathrm{E}-06 \\
(0.000)\end{array}$ \\
\hline Toll yes/no & $\begin{array}{l}- \\
-\end{array}$ & $\begin{array}{l}- \\
-\end{array}$ & $\begin{array}{l}- \\
-\end{array}$ & $\begin{array}{l}- \\
-\end{array}$ \\
\hline $\begin{array}{l}\text { Bus lane } \\
\text { yes/No }\end{array}$ & $\begin{array}{l}- \\
-\end{array}$ & $\begin{array}{l}- \\
-\end{array}$ & - & $\begin{array}{l}- \\
-\end{array}$ \\
\hline Major city & - & - & $\begin{array}{l}- \\
-\end{array}$ & - \\
\hline R-squared & 0.803 & 0.877 & 0.728 & 0.877 \\
\hline
\end{tabular}

Figure 2 Regional Short Range Personal Predicted Vs. Real Values

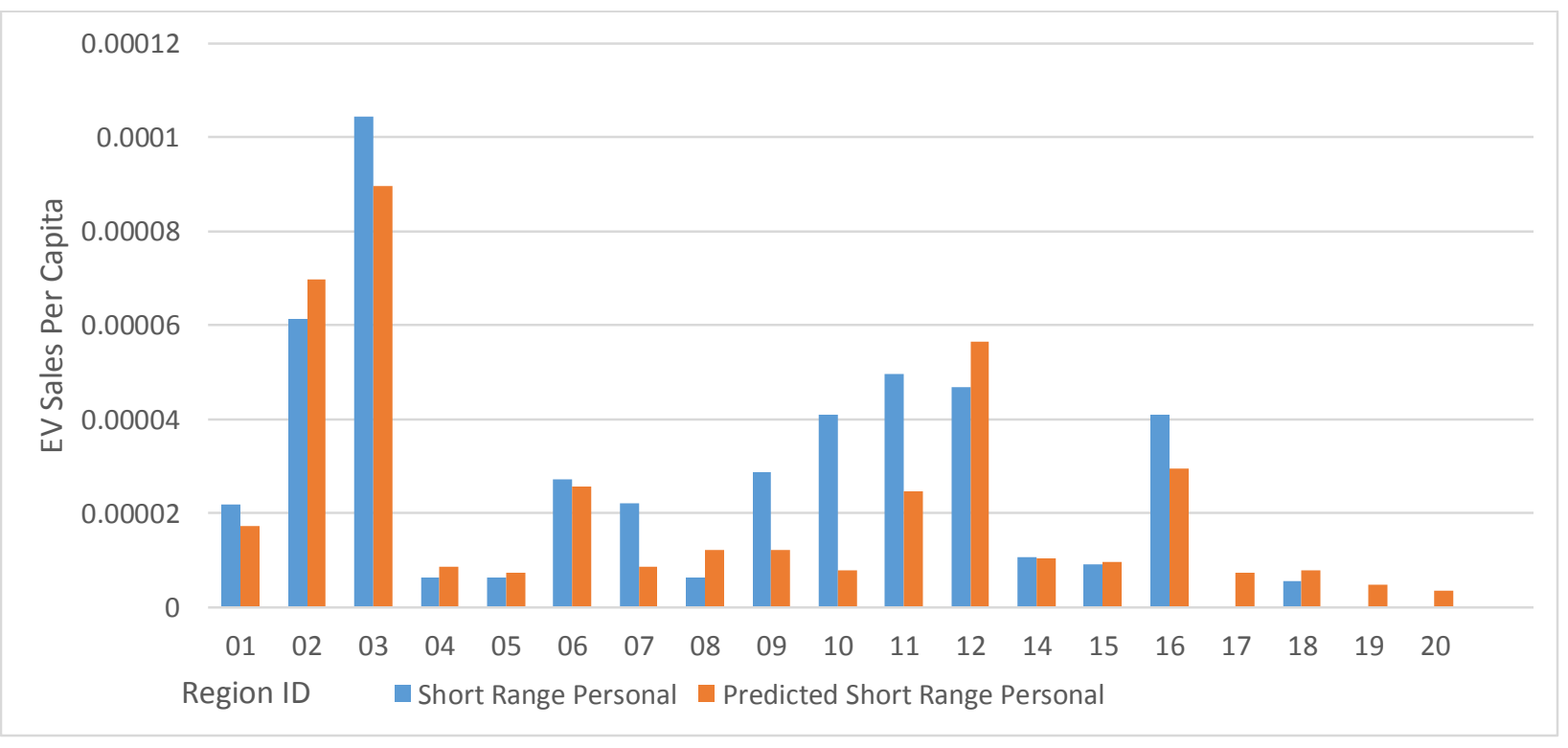


Figure 3 Regional Long Range Personal Predicted Vs. Real Values

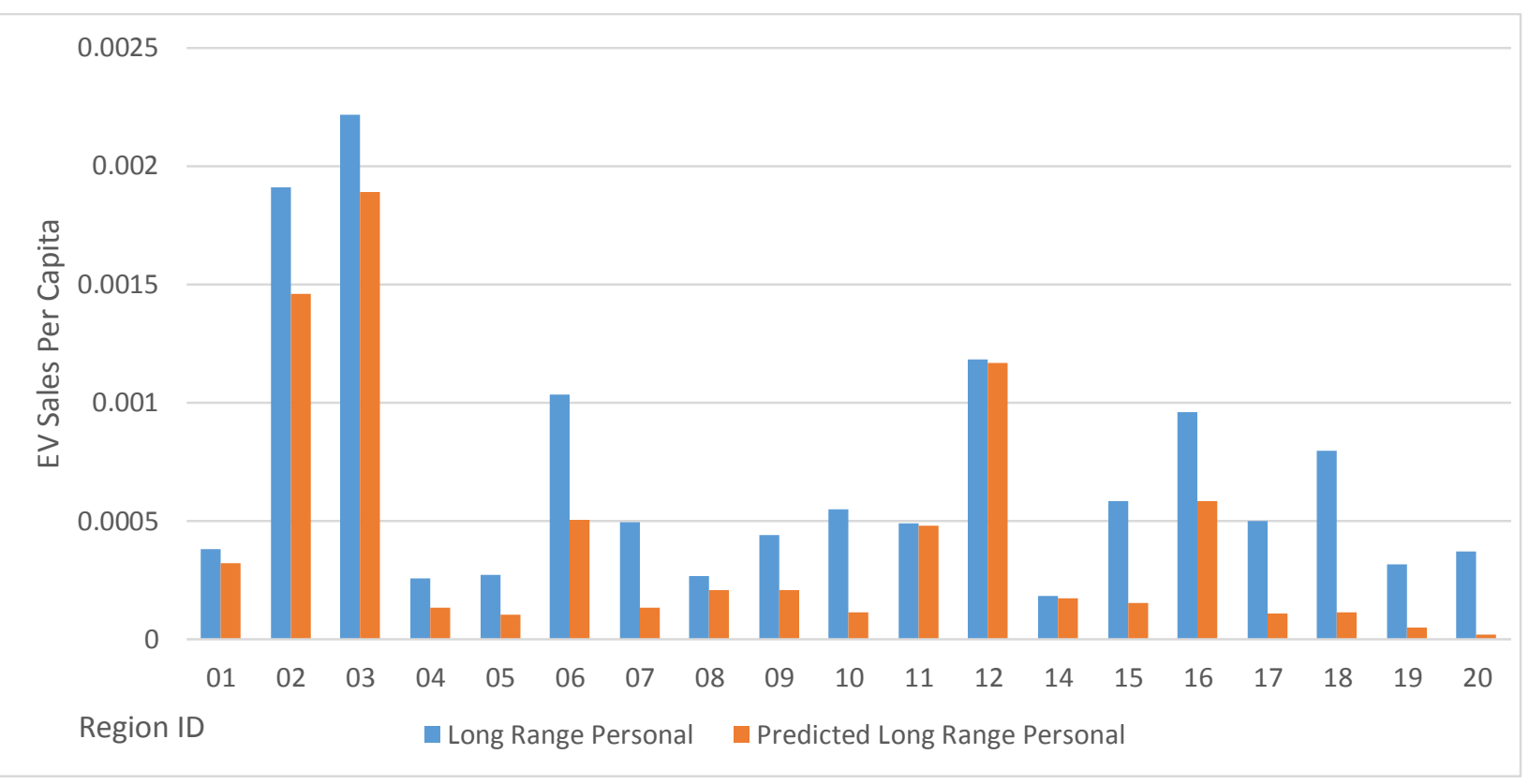

Figure 4 Regional Short Range Business Predicted Vs. Real Values

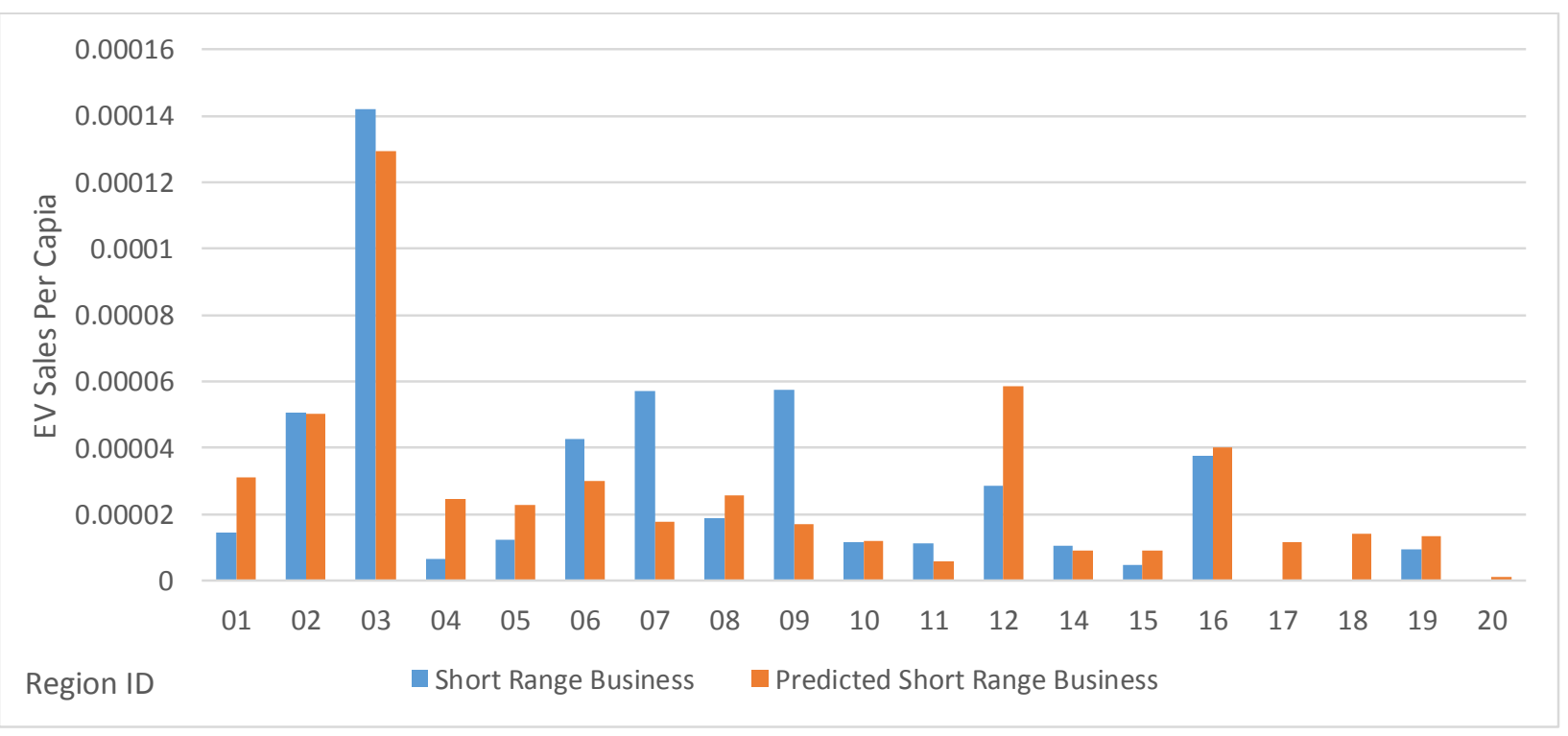

5

6 
Figure 5 Regional Long Range Business Predicted Vs. Real Values

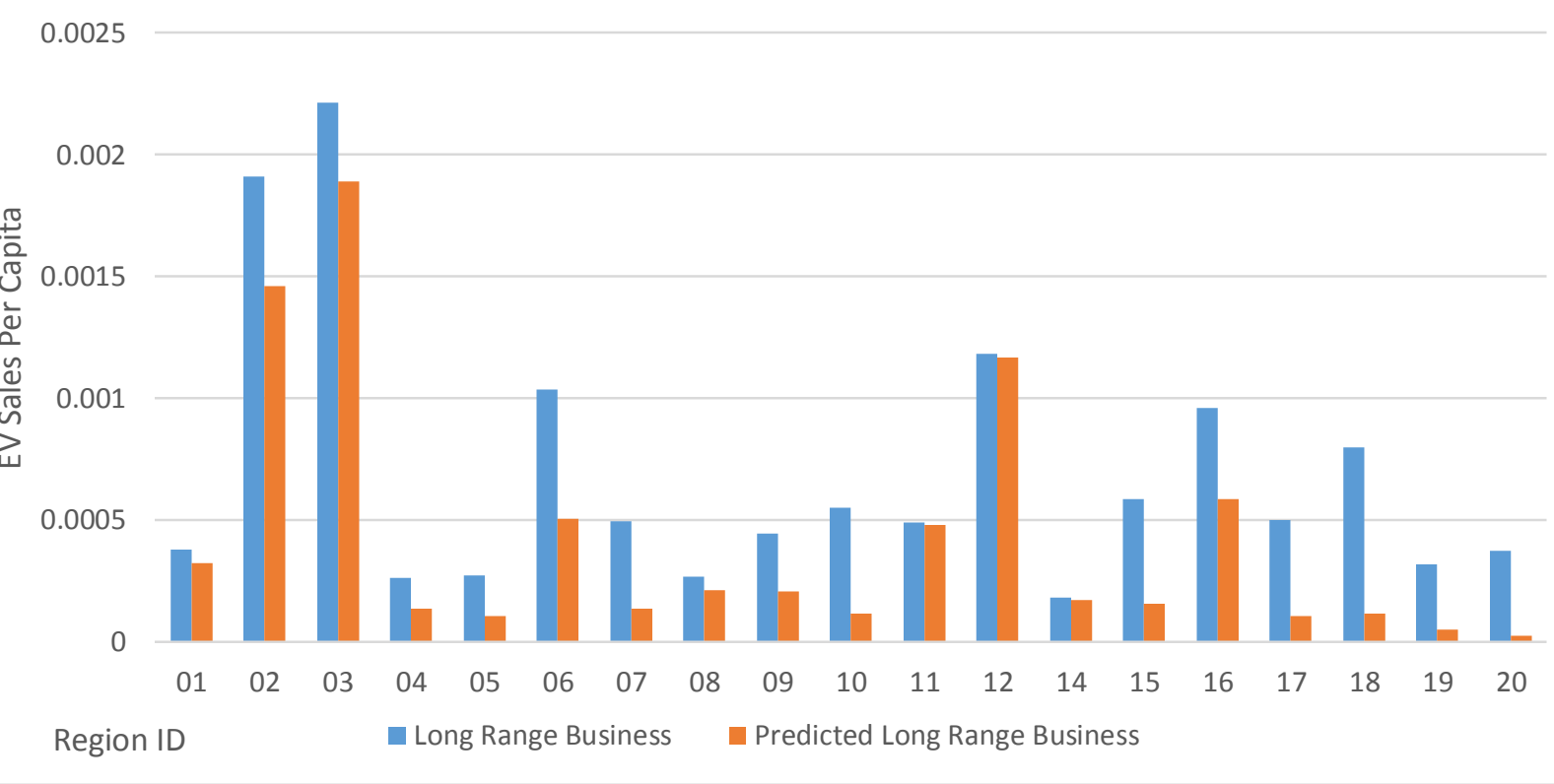

\section{DISCUSSION AND CONCLUSIONS}

\subsection{Regional}

Among all the predictors, the number of EV charging stations was found to have the highest predictive power for regional per capita sales. On the linear regional models, no other measure was found to add significantly to its predictive abilities, with the exception of income for shortrange corporate EVs. It should also be noted that for short-range corporate EVs the P-value for regional income was relatively low, at 0.011 . This shows relatively high certainty about the accuracy of its effect in the model. Interestingly, while the coefficient on the number of charging stations is positive, the coefficient on income is negative. So while increases in the number of available charging stations increase the expected per capita sales of EVs, increase in median household income decrease expected sales per capita in one case. However the model where that applies is for short-range corporate vehicles. While the result might not be expected, a possible cause is that people in higher income areas would demand better corporate vehicles and the companies respond by buying fewer short-range vehicles and more long-range ones. The presence of tolls and/or bus lanes was found to not be significant enough to be included, possibly due to the fact that on the regional level they are highly correlated with chagrining stations themselves.

It cannot be determined from this study if correlation of per capita sales with charging stations is purely due to the consumer incentive effect of the charging stations, or if the charging stations are being built in response to local EV demand. In addition, it could be expected for the government to focus its resources for EV chargers on the localities with the most need - those with or expected to have the most EVs. The importance of charging stations for sales of EVs is highlighted in Sierzchula et al (2014), which find it to be the best predictive factor. State preference and survey studies also find refueling possibilities an important factor for the 
adoption of a range of alternative fueled vehicles including EVs (Achtnicht et al, 2012, Egbue and Long, 2012, Tran et al, 2012).

\subsection{Municipal}

The municipal models are more complex than the regional models, as the variables differ with each municipal group studied. For both groups of private consumers the income is positive and significant, which is expected since EVs have a relative high purchasing price and an increase in discretionary spending ability enables the purchase of additional household vehicles. Most households that have bought an EV have at least one other vehicle (Erik Figenbaum and Marika Kolbenstvedt, 2013). Stated preference studies have found income to be an important factor (Hidrue, M. K. et al., 2011) while studies that have looked at cross country data on EV sales find it less conclusive (Sierzchula et al., 2014; Sprei and Bauner, 2011), likely due to the low sales numbers rather than a real effect.

13 Another factor in common for both private consumer models is the closeness to a major city for which the long-range case is more significant. The lower effect on short-range vehicles might be due to the fact that these are less often used for commuting longer distances such as to a neighboring municipality. Another explanation is that bus lanes are correlated with this variable and since in the short-range model this variable appears as well, part of the effect might be included there. Earlier EV market research, in Norway, supports access to bus-lanes as an important reason for purchasing EVs. The major city variable might also explain why road tolls are not significant since it might capture their effect despite EVs often being used as commuter vehicles (Hjorthol, Randi, 2013).

Vehicle Kilometers Traveled was negatively correlated with long-range personal sales. This could be representative of EV ranges not being viable for long distance commuters or just generally that people that travel long distances might have a driving pattern that is less suitable for EVs (Plötz, Patrick et al., 2014) . Municipalities with greater percentages of commuters should have higher VKTs and most commutes should be within a 100km round trip range.

For the business purchasers, increases in unemployment were correlated with increased shortrange corporate vehicle sales. This can be seen as the corollary of the income effect seen in the regional models; decreased employee bargaining power or wages appears to lead to an increase in short range vehicle sales. Its absence in long-range corporate sales seems to suggest that corporate demand for long-range vehicles is less elastic than for short range ones, an inference supported by the regional models. The reason for this is unclear, but it could be due to the nature of the corporate purchases. For instance, this would be expected if the short-range vehicles are used for shuttling employees or as perks, while long-range vehicles are being used in fleets, such as delivery vans and taxis. The short-range vehicles would then be elastic with respect to employee bargaining power while the long-range vehicles would instead be elastic with respect to direct usability considerations. Determining the reasons would require a survey into why corporations purchase their EVs. Also, since VAT is generally not paid for corporate vehicles the level of subsidies for corporate vehicles is much lower compared to private consumers and thus 
The number of charging stations was found to be significant for business sales on the municipal level. This might reflect the needs of fleet vehicles, rather than corporate cars for employee usage. A taxi is expected to mainly operate in one municipality, where it was given license, and only leave if a customer requests it. For this reason, those purchases would be particularly sensitive to the intra-municipality charging potential. Other users who regularly cross such boundaries might be more interested in the number of charging points in the vicinity. This may be seen in the major city binary, which is significant and positive for all groups. As city population is also correlated with higher numbers of charging points, as well as higher tolls and more exclusive bus lanes, this suggest that people who cross municipal boundaries are particularly interested in these features. That is people may be more likely to buy an EV if they are near a major city and are commuting into the city because they can take advantage of its EV infrastructure (Hjorthol, Randi, 2013).

In the long-range business model bus lanes also were significant, this may also be related to commuting. A portion of the business vehicles are vehicles provided by the employer as part of the wages. The employee can then use the vehicle to commute to work.

\subsection{Municipal vs. Regional}

The Municipal linear regressions had significantly decreased goodness of fit relative to the regional ones; with municipal $\mathrm{R}$ squared values varying between .06 and .22 while all regional values were above .73 and having decreased complexity. The municipal regression models were all more varied in terms of which predictors were represented in the final model. This is possibly due to the low absolute sales numbers for many of the municipalities, allowing for the random element of sales to overtake the effect of the incentives. In addition, all municipal models had the major city binary in their final model. Major cities were also all correlated with more bus exclusive lanes, tolls, limited/expensive parking, and charging stations. It can be assumed that this means that municipal buyers are sensitive to some combination of these measures in their greater vicinity and not only their municipality. It may also reflect that the buyers commute to a larger municipality but that they stay in the same region. For the regional models, the number of charging points was the most useful variable, being the sole important variable for all but one model and used in every model. This also supports the previous inference as it shows buyers reacting to the number of charging stations that they would have access to, beyond their municipal borders.

\section{$32 \quad 5.4$ Long Range vs. Short Range}

33 Short range vehicles showed somewhat more income and unemployment sensitivity than long range vehicles, with one of the measures being included in three out of the four linear short range models and only one of the long range models. For corporate sales, this could be a reaction to employee bargaining power. Unemployment rate was significant in determining the per capita sales of short range business cars on the municipal level. Specifically, short-range corporate EV sales increased with unemployment, by itself counter intuitive. In the regional model, short-range corporate EV sales decreased with increases in household income, a similarly counter intuitive result. It is also worth noting here that the models were allowed to contain both unemployment and household income as they were found to be very weakly correlated, with an R squared of .09

42 on the municipal level. 


\subsection{Business vs. Consumers}

On the municipal level, corporate vehicles were much more sensitive than personal vehicles to the number of charging stations. This could be due to the effect of taxi fleets and other operators, whose service is limited by those same political boundaries. It is worth mentioning that all municipal models had the major city binary in their final model. As major cities are also correlated with larger numbers of charging points and personal vehicles do not have the same municipal boundary restrictions as some fleets, this would seem to support the above conclusion. Private consumers may also be less dependent on public charging since they can fill up their battery at home and cover most of the days driving on that charge. Also as stated above, short range corporate sales seem to be influenced by factors relating to employee bargaining power, increasing with unemployment, on the municipal level, where labor is in greater supply; and decreasing with higher incomes on the regional level, possible reflecting higher skills. Personal municipal sales on the other hand, were more sensitive to hou sehold incomes. This would seem to reflect household budget constraints. This may be supported with rising VKTs indicating decreases in long range personal vehicle sales. Commuters may believe that the short range EVs are sufficient for their needs. Additionally, corporate sales are much lower than personal sales on a per capita basis. Mainly due to the fact that the VAT exemption does not affect them since corporations can deduct VAT from purchases and thus the price difference between EV and conventional vehicles increases. It is also important to note that the data does not allow an analysis that distinguishes between corporate fleet vehicles and those made available to employees for personal and commuting usage. Both of these could be expected to be affected differently by the investigated factors.

\subsection{Policy Implications}

The results of this study lead to some policy recommendations for localities that wish to increase EV sales. These recommendations can be separated into two sets: one for small localities, similar in size and population to the municipalities studied, and another for large, region sized, localities/legal units, corresponding in size and/or population to the regions included in this study. For the smaller localities, two recommendations could be made. The first is to create or increase pricing incentives for EVs. While this study did not directly investigate pricing incentives, as they were uniform throughout Norway, the correlations with income for personal sales suggest an element of price sensitivity. Combined with the previously noted findings (Achtnicht, Martin et al., 2012; Berensteanu, A. and Li, S, 2011; Bjerkan et al., 2016; Chandra, A. et al., 2010; Gallagher and Muehlegger, 2011; Håvard Vaggen Malvik et al., 2013; Jenn et al., 2013; Sierzchula et al., 2014), this recommendation is supported internationally. For business BEV sales, increasing the availability of charging stations may incentivize purchases of EVs. However, this study cannot determine if EV sales were increased by the presence of charging stations or vice versa. A similar recommendation can be applied for regional sized localities, with increasing access to charging stations appearing to be the best policy option, again with the caveat that it cannot be determined from this study alone if EVs incentivize the construction of charging stations or the opposite. Toll exemptions and the right to use bus designated lanes do not seem to have statistically significant predictive power for BEV sales in our linear municipallevel models, but this could be due to neighboring major cities containing those incentive features. 


\section{SUMMARY}

While electric vehicles could provide significant benefits relating to energy diversity, environment and public health, they currently require a purchase premium and lack a robust refueling infrastructure. Norway has the longest and most extensive national campaign to encourage EV adoption. This study investigated the effects of many of the incentives on per capita EV sales among the municipalities and regions (counties) of Norway. Basic economic data and EV infrastructure data were collected for these municipalities along with EV sales data, grouped by vehicle range and owner. Optimal linear regressions were run to see which variables were most useful for predicting per capita EV sales. On the regional level it was concluded that the number of charging stations had the highest indicative effect, though not necessarily causal. On the municipal level personal vehicles were found to be sensitive to median household income while corporate vehicles were sensitive the number of charging stations. Additionally, all municipal EV sales were found to be sensitive to the presence of major cities; possibly providing a proxy for tolls, exclusive access bus lanes, charging stations, or just customers leaving the neighboring major city, to purchase their EVs, in other areas. There were also differences observed between short and long-range vehicles, with short-range vehicles being much more sensitive to economic measures, specifically income and unemployment. Combined, these suggest that pricing incentives and increased access to charging stations may be the best policies to increase EV sales.

\subsection{Limitations}

Certain Norwegian government incentives could not be analyzed in this study. Access to free parking could not be analyzed due to lack of data on the number of spots open on a municipal basis. In addition, all incentives that the consumer would see in the point of sale price are also ignored. This is due to the fact that all the pricing incentives are given nationally, allowing for no difference to be seen on a single nation study.

\subsection{Future work}

Future work should focus on answering the questions made evident in the study. In particular this study, by focusing on broad EV groups and looking at municipal and regional demographic and incentive data, did not consider much of the effect of price-demand elasticity. The prices and vehicle characteristics of BEVs are important features for BEV sales, and should be investigated. In addition, a time-scaled study, investigating how consumers respond to short and long-term trends in gas pricing would have benefit. Investigation of vehicle purchase pricing sensitivity, which previous studies have suggested to be one of the primary drivers (Global EV Outlook, 2013; Peter Mock and Zifei Yang, 2014; Sierzchula et al., 2014; Sprei and Bauner, 2011), however, would require expanding the investigation to other countries. This is due to the fact that the purchase pricing incentives for EVs are nationally based in Norway. Another study, based on post vehicle purchase questionnaires and similar to or used Bjerkan et al's results (Bjerkan et al., 2016), may help tease out the effects of some of the incentives more easily. Proximity to cities was seen as important, but its cross correlation with incentives, such as bus lane access and free parking, made it difficult to see their joint effect. In addition this may allow us to see which vehicles EVs were being compared against and see how important features, like range, are as incomes and number of owned vehicles changes. 


\section{Acknowledgements}

This research was supported in part by the Center for Climate and Energy Decision Making (SES-0949710) through a cooperative agreement between the NSF and Carnegie Mellon University. Financial support was also provided by the Area of Advance Transport at Chalmers University of Technology.

\section{REFERENCES}

Achtnicht, Martin, Bühler, Georg, and Hermeling, Claudia (2012), 'The impact of fuel availability on demand for alternative-fuel vehicles', Transportation Research Part D: Transport and Environment, 17 (3), 262-69.

Achtnicht, Martin, Bühler, Georg, Hermeling, Claudia, 2012. The impact of fuel availability on demand for alternative-fuel vehicles. Transp. Res. Part Transp. Environ. 17, 262-69.

Alternative Fueling Station Counts by State [WWW Document], 2014. . US Dep. Energy. URL http://www.afdc.energy.gov/fuels/stations_counts.html (accessed 7.29.14).

Axsen, J., Kurani, K.S., 2013. Hybrid, plug-in hybrid, or electric - What do car buyers want? Energy Policy 61, 532 - 543. doi:http://dx.doi.org/10.1016/j.enpol.2013.05.122

Axsen, J., Mountain, D.C., Jaccard, M., 2009. Combining stated and revealed choice research to simulate the neighbor effect: The case of hybrid-electric vehicles. Resour. Energy Econ. 31.

Berensteanu, A., Li, S, 2011. Gasoline prices, Government support, and the demand for hybrid vehicles in the United States. Int. Econ. Rev. 52, 161-183.

Bjerkan, K.Y., Nørbech, T.E., Nordtømme, M.E., 2016. Incentives for promoting Battery Electric Vehicle (BEV) adoption in Norway. Transp. Res. Part Transp. Environ. 43, 169180. doi:10.1016/j.trd.2015.12.002

Bolduc, D., Boucher, N., Alvarez-Daziano, R., 2008. Hybrid Choice Modeling of New Technologies for Car Choice in Canada. Transp. Res. Rec. J. Transp. Res. Board 2082, 63-71. doi:10.3141/2082-08

Brownstone, D., Bunch, D.S., Train, K., 2000. Joint mixed logit models of stated and revealed preferences for alternative-fuel vehicles. Transp. Res. Part B Methodol. 34, 315-338. doi:10.1016/S0191-2615(99)00031-4

Chandra, A., Gulati, S., Kandlikar, M., 2010. Green drivers or free riders? An analysis of tax rebates for hybrid vehicles. J. Environ. Econ. Manag. 78-93.

De Haan, P., Peters, A., Scholz, R.W., 2007. Reducing energy consumption in road transport through hybrid vehicles: investigation of rebound effects, and possible effect of tax rebates. J. Clean. Prod. 15, 1076-1084.

Diamond, D., 2009. The impact of government incentives for hybrid-electric vehicles: Evidence from US states. Energy Policy 37, 972-983. doi:10.1016/j.enpol.2008.09.094

Electric Vehicle Incentives around the world [WWW Document], 2014. . Tesla. URL http://www.teslamotors.com/incentives/US (accessed 7.22.14). 
Eppstein, M.J., Grover, D.K., Marshall, J.S., Rizzo, D.M., 2011. An agent-based model to study market penetration of plug-in hybrid electric vehicles. Energy Policy 39, 3789-3802. doi:10.1016/j.enpol.2011.04.007

Erik Figenbaum, Marika Kolbenstvedt, 2013. Electromobility in Norway - experiences and opportunities with Electric vehicles (TØI report No. 1281). Institute of Transportation Economics, Oslo.

Find a toll station [WWW Document], 2013. . Autopass. URL http://www.autopass.no/en/autopass (accessed 7.1.14).

Gallagher, K.S., Muehlegger, E., 2011. Giving green to get green? Incentives and consumer adoption of hybrid vehicle technology. J. Environ. Econ. Manag. 61, 1-15. doi:10.1016/j.jeem.2010.05.004

Global EV Outlook, 2013. . IEA.

Greene, D.L., Park, S., Liu, C., 2014. Analyzing the transition to electric drive vehicles in the U.S. SI Low Carbon Futur. 58, 34-52. doi:10.1016/j.futures.2013.07.003

Grønn Bil [WWW Document], 2014. URL http://www.gronnbil.no/english (accessed 7.22.14).

Håvard Vaggen Malvik, Ole Henrik Hannisdahl, Guro Bøe Wensaas, 2013. The future is electric! The EV revolution in Norway - explanations and lessons learned, in: ECEEE Summer Study Proceedings. Presented at the ECEEE Summer Study.

Hidrue, M. K., Parsons, G. R., Kempton, W., Gardner, M. P., 2011. Willingness to pay for electric vehicles and their attributes. Resour. Energy Econ. 33, 686-705.

Hjorthol, Randi, 2013. Attitudes, ownership and use of Electric Vehicles - a review of literature (TØI report No. 1261/2013).

Holdway, A.R., Williams, A.R., Inderwildi, O.R., King, D.A., 2010. Indirect emissions from electric vehicles: emissions from electricity generation. Energy Environ. Sci. 3, 18251832. doi:10.1039/C0EE00031K

Households' income, geographic distribution [WWW Document], 2014 . Stat. Nor. URL https://www.ssb.no/statistikkbanken/SelectVarVal/Define.asp?MainTable=InntektStruk1 $3 \&$ KortNavnWeb=inntgeo\&PLanguage $=1 \&$ checked=true $($ accessed 7.23.14).

Jenn, A., Azevedo, I.L., Ferreira, P., 2013. The impact of federal incentives on the adoption of hybrid electric vehicles in the United States. Energy Econ. 40, 936-942. doi:10.1016/j.eneco.2013.07.025

Mau, P., Eyzaguirre, J., Jaccard, M., Collins-Dodd, C., Tiedemann, K., 2008. The "neighbor effect": Simulating dynamics in consumer preferences for new vehicle technologies. Ecol. Econ. 68, 504-516. doi:10.1016/j.ecolecon.2008.05.007

Michalek, J.J., Chester, M., Jaramillo, P., Samaras, C., Shiau, C.-S.N., Lave, L.B., 2011. Valuation of plug-in vehicle life-cycle air emissions and oil displacement benefits. Proc. Natl. Acad. Sci. doi:10.1073/pnas.1104473108

Michalek, J.J., Chester, M., Samaras, C., 2012. Getting the Most Out of Electric Vehicle Subsidies. Issues Sci. Technol. 28, 25-27.

Mueller, M.G., de Haan, P., 2009. How much do incentives affect car purchase? Agent-based microsimulation of consumer choice of new cars-Part I: Model structure, simulation of bounded rationality, and model validation. Energy Policy 37, 1072-1082. doi:10.1016/j.enpol.2008.11.002

National Research Council, 2013. Transitions to Alternative Vehicles and Fuels. The National Academies Press, Washington, DC. 
Opplysningsrådet for Veitrafikken [WWW Document], n.d. URL http://www.ofv.no/ (accessed 7.31.14).

Peter Kennedy, 2008. A guide to Econometrics, 6th ed. Blackwell Publishing, Malden.

Peter Mock, Zifei Yang, 2014. Driving Electrification - a global comparison of fiscal incentive policy for electric vehicle (White Paper). ICCT.

Plötz, Patrick, Jakobsson, Niklas, Sprei, Frances, Karlsson, Sten, 2014. On the distribution of individual daily vehicle driving distances.

Population [WWW Document], 2014. . Stat. Nor. URL https://www.ssb.no/statistikkbanken/selectvarval/Define.asp? subjectcode $=\&$ ProductId= \& MainTable $=$ BeregnFolkem $\&$ nvl $=\&$ PLanguage $=1 \&$ nyTmpVar $=$ true $\& C M S S u b j e c t A r e a=$ befolkning \&KortNavnWeb=folkemengde $\&$ StatVariant $=\&$ checked=true $($ accessed 7.23.14).

Prosam, 2009. Trafikk i kollektivfelt: kapasitet og avvikling; elbilens rolle. (Prosam rapport No. 176).

Registered unemployed [WWW Document], 2014. . Stat. Nor. URL https://www.ssb.no/statistikkbanken/selectvarval/Define.asp? subjectcode=\&ProductId=\& MainTable $=$ Rd1603Aa\&nvl=\&PLanguage $=1 \&$ nyTmpVar=true $\& C M S S u b j e c t A r e a=a r b e i$ d-og-lonn\&KortNavnWeb=regledig\&StatVariant=\&checked=true (accessed 7.23.14).

Samaras, C., Meisterling, K., 2008. Life Cycle Assessment of Greenhou se Gas Emissions from Plug-in Hybrid Vehicles: Implications for Policy. Environ. Sci. Technol. 42, 3170-3176. doi:10.1021/es702178s

Sánchez-Braza, A., Cansino, J.M., Lerma, E., 2014. Main drivers for local tax incentives to promote electric vehicles: The Spanish case. Transp. Policy 36, 1-9. doi:10.1016/j.tranpol.2014.06.010

Sierzchula, W., Sjoerd Bakker, Kees Maat, Bert van Wee, 2014. The influence of financial incentives and other socio-economic factors on electric vehicle adoption. Energy Policy 68, 183-94.

Skerlos, S.J., Winebrake, J.J., 2010. Targeting plug-in hybrid electric vehicle policies to increase social benefits. Energy Policy 38, 705-708. doi:10.1016/j.enpol.2009.11.014

Sprei, F., Bauner, D., 2011. Incentives impact on EV markets - Report to the Electromobility project (Report to the Electromobility project). Viktoria Institute, Gothenburg.

Traut, E.J., Cherng, T.C., Hendrickson, C., Michalek, J.J., 2013. US residential charging potential for electric vehicles. Transp. Res. Part Transp. Environ. 25, 139-145. doi:10.1016/j.trd.2013.10.001

Vehicle Kilometers Travelled [WWW Document], 2014. . Stat. Nor. URL https://www.ssb.no/statistikkbanken/selectvarval/Define.asp?subjectcode=\&ProductId=\& MainTable $=$ KjoreLengderGjSn\&nvl $=\&$ PLanguage $=0 \&$ nyTmpVar $=$ true $\& C M S S u b j e c t A r$ ea=transport-og-reiseliv \&KortNavnWeb=klreg\&StatVariant=\&checked=true $($ accessed 7.28.14).

Working time in the European Union: Norway [WWW Document], 2009. . Eur. Work. Cond. Obervertory. URL http://www.eurofound.europa.eu/ewco/studies/tn0803046s/no0803049q.htm (accessed 7.23.14). 